\title{
ARTICLE \\ Environmental variability at a marine cage culture operation in the Matanchén Bay, SE Gulf of California, Mexico
}

Variabilidad ambiental en un cultivo de jaulas marinas en la Bahía Matanchén, SE del Golfo de California, México

\author{
Eulalio Arámbul ${ }^{1}$, Sergio G. Castillo-Vargasmachuca ${ }^{1}$, Jesús T. Ponce-Palafox ${ }^{1 *}$, \\ Federico Páez-Osuna ${ }^{2}$, José Luis Arredondo-Figueroa ${ }^{3}$ and Héctor M. Esparza-Leal ${ }^{4}$
}

\author{
${ }^{1}$ Programa de Posgrado de Maestría en Ciencias Biológico Agropecuarias, Laboratorio de Bioingeniería Costera, Universidad \\ Autónoma de Nayarit, Tepic, Nayarit, México 63000.*jesus.ponce@usa.net \\ ${ }^{2}$ Instituto de Ciencias del Mar y Limnología, Universidad Nacional Autónoma de México, Unidad Académica Mazatlán, Joel \\ Montes Camarena s/n, Mazatlán, Sinaloa, México 82040 \\ ${ }^{3}$ Universidad Autónoma de Aguascalientes, Posta Zootécnica, Jesús María, Aguascalientes, México 20131 \\ ${ }^{4}$ Instituto Politécnico Nacional, CIIDIR Unidad Sinaloa, Boulevard Juan de Dios Bátiz Paredes \#250, Guasave, Sinaloa, \\ México 81101
}

\begin{abstract}
Resumen.- Este trabajo presenta los resultados del análisis de las condiciones ambientales sobre el perfil físico-químico de la columna de agua y sedimentos que son producidos por las jaulas flotantes y la influencia de escurrimientos continentales en una granja de peces marina en el Sur este del Golfo de California, México. Veinte muestras de la columna de agua y siete del sedimento fueron colectadas mensualmente durante un ciclo anual. Se analizaron parámetros físicoquímicos del agua y del sedimento. En general, los nitratos mostraron la más alta concentración de los nutrientes en las estaciones de la zona de impacto potencial $\left(1,92 \mathrm{mg} \mathrm{L}^{-1}\right)$. Hubo una variación temporal en la concentración de $\mathrm{NH}_{4}{ }^{+}, \mathrm{NO}_{3}{ }^{-} \mathrm{Y}$ $\mathrm{PO}_{4}{ }^{3-}$ en la columna de agua, y en la concentración de arcilla y materia orgánica en sedimento, con una tendencia a incrementarse en las estaciones de impacto potencial y control, respectivamente.
\end{abstract}

Palabras clave: Acuacultura marina, impacto ambiental, calidad del agua, calidad del sedimento

\begin{abstract}
This study investigated the environmental impact of offshore floating sea cages and the influence of runoff on cage fish farming in SE Gulf of California via the analysis of the physico-chemical profiles of the water column and sediments, located in SE Gulf of California, Mexico. Water and sediment samples were analyzed for physico-chemical parameters. In general, nitrates showed the highest concentrations of nutrients in the potential impact station $\left(1.92 \mathrm{mg} \mathrm{L}^{-1}\right)$. The results displayed temporal variations in the $\mathrm{NH}_{4}{ }^{+}, \mathrm{NO}_{3}$, and $\mathrm{PO}_{4}{ }^{3-}$ in the water column as well as variations in the clay and organic matter in the sediment. The observed trends of these parameters were toward higher concentration in the potential impact and control stations.
\end{abstract}

Key words: Marine aquaculture, environmental impact, water quality, sediment quality

\section{INTRODUCTION}

Marine finfish cage aquaculture has been developed in various regions of the world with great success (Price et al. 2015). However, this development has been accompanied by environmental risk. Nowadays, there is strong interest in advancing an industry ever more profitable but in harmony with the environment (Grigorakis \& Rigos 2011). Regional efforts have been made in most of the areas where floating sea-cage aquaculture has grown (Holmer 2010). One of the main challenges facing sea-cage aquaculture is the impact of the wastes from sea farms on organisms in the surrounding areas (Price $e t$ al. 2015). The impact of these wastes can be reduced through improved feed and proper location of farms (Grøttum \& Beveridge 2007). Finfish aquaculture in floating sea cages has been carried out in three zones: onshore, nearshore, and offshore (Holmer 2010). In recent years, Mexico has developed a program to support development of finfish culture in floating sea cages off the coast (i.e., farms located $500 \mathrm{~m}$ to $3 \mathrm{~km}$ from nearshore and at a water depth of 10 to $50 \mathrm{~m}$ ). Currently, the information on the environmental effects on off-coast farms is limited due to 
the relatively few full-scale off-coast farms under operation. Studies on the management of floating seacage fish farming have evaluated the visual impact and ecological footprint, benthic impacts, interactions with wild fish and predators, use of antifoulants/chemicals, carbon footprint, and water quality (Holmer 2010). Sediment impacts are of primary concern in mariculture, particularly where accumulation of organic matter may result in anoxia/hypoxia and losses of benthic production and biodiversity (Hargrave et al. 2008). Water quality is one of the factors that may have less severe impacts (Sara 2007). The principal source of wastes in floating sea cages is organic matter coming from the fish feed and feces (Sanz-Lázaro \& Marín 2011). It has been found that approximately $1 / 4$ of the nutrients supplied via fish feed are incorporated into the fish meat itself, and $3 / 4$ is widely dispersed, with fast sinking rates of feed pellets and feces causing organic enrichment of the bottom sediments in farm vicinities (Holmer et al. 2005, Holmer 2010). Water quality is affected by the release of dissolved and particulate inorganic and organic nutrients. However, limited impacts have been recorded in many places due to rapid dispersal (Holmer 2010). Since the shelf area in Mexico has not been widely monitored with respect to the impacts of organic enrichment and the influence of the mainland on farming systems, research related to expansion of off-coast cage aquaculture in the region is still needed. The aim of this study was to analyze the water and sediment variability near a sea-cage fish farm, and to evaluate the influence of continental runoff into sea cages located in the Bay Matanchén, at the mouth of southeastern Gulf of California, Mexico.

\section{Materials AND METHODS}

\section{STUDY AREA}

This study was conducted at the Matanchén Bay on the eastern coast of the mouth of the Gulf of California (Fig. 1). The site is known as 'Punta el Caballo' beach along the Nayarit coast, Mexico (21 $\left.{ }^{\circ} 25^{\prime} 55.44^{\prime \prime} \mathrm{N}, 105^{\circ} 12^{\prime} 26.63^{\prime \prime} \mathrm{W}\right)$. The cultivation area is located at $0.514 \mathrm{~km}$ from the mouth of the Naranjo River $\left(21^{\circ} 26^{\prime} 03.01^{\prime \prime} \mathrm{N}, 105^{\circ} 12^{\prime} 12.17^{\prime \prime} \mathrm{W}\right)$, within the area of influence of riverine discharges during the flood season, mainly due to the contribution of total solids (Castillo-Vargasmachuca et al. 2012). The sea-cage fish farming facility is located in the open sea, about $1.5 \mathrm{~km}$ from the coastline within the polygon concession allocated to the Cooperative 'Blakis in Progress S.C. of
R.L' in Santa Cruz de Miramar, San Blas, Nayarit. This area has a floating sea-cage fish farm producing 30 tons year $^{-1}$ of snapper and tilapia over two cycles per year. The culture farm comprised two sets of 10 floating cages each $(5 \times 5 \times 5 \mathrm{~m})$, constructed with nylon-10 (tarred polyamide) netting each. The cages were equipped with 200-L plastic and 50-L glass sealed drums as the flotation system, suspended $15 \mathrm{~m}$ above the sandy bottom, $5 \mathrm{~m}$ apart, and aligned to the main Pacific current. These cages were used to rear snapper Lutjanus guttatus and L. peru (Castillo-Vargasmachuca et al. 2007, Castillo-Vargasmachuca et al. 2012) as well as tilapia Oreochromis niloticus. This unit had been operating for 2 years (4 production cycles) when our investigation started of the 5 th production cycle. The culture strategy was one phase. The fish were fed daily using commercial feed (NUTRIPEC-Purina: $42 \%$ protein, $12 \%$ lipids, and $10 \%$ moisture), dispensed manually from a small boat.

\section{SAMPLing STRATEGY}

This study covered a one-year cycle with measurements taken from selected sampling points that are located inside and around the cage system and are separated by a mean distance of about $500 \mathrm{~m}$. The particular unit monitored was a group of 10 cages, arranged in a northwestsoutheast direction. The water depth at this site ranged from 18 to $20 \mathrm{~m}$, the mean current velocity was $10.4 \pm 2.0$ $\mathrm{cm} \mathrm{s}^{-1}$ and the predominated directions were NW-SE, as measured (more than $80 \%$ of the time) by an automatic current-meter (Aanderaa Instruments, Inc. Mod. RCM-7, Norway). Twelve sampling stations were established to determine the seasonal changes in the physico-chemical profiles of water and sediment. Samples of the water column were collected monthly during an annual cycle and grouped into three zones and seasons of the year for analysis: 4 points as the facility ( 2 in cages and 2 outside cages); 4 upstream sampling areas as the controls; and 4 points in the impact downstream of the farm. At each sampling point, samples were collected from the surface $(0 \mathrm{~m})$, mid-water $(10 \mathrm{~m})$, and the bottom (20 m) (Fig. 2). In total, there were 8 stations, 200 to $500 \mathrm{~m}$ away from the facility, and four positioned in floating cages, downstream in the main current direction (Fig. 1). Samples of water and sediment were collected during 12 sampling trips (September 2014 through August 2015). In the sampling stations, samples of unaltered sediment layers were taken using a Van Veen grab $\left(0.1 \mathrm{~m}^{2} ; 20 \mathrm{~L}\right)$ equipped with screen doors. In four stations of the sediments, the sample was 


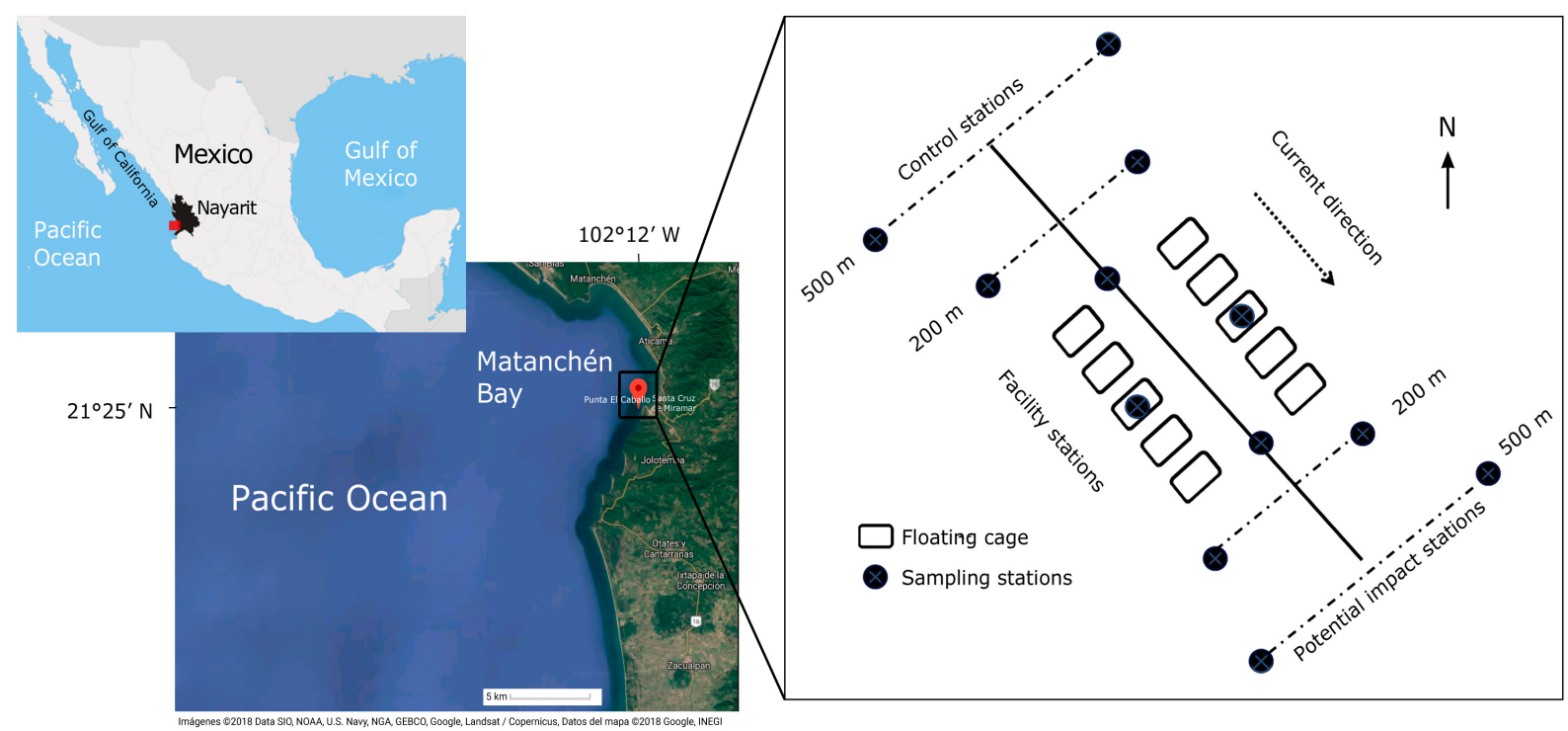

Figure 1. Study area and sampling stations at the Matanchén Bay, Nayarit coast, Mexico / Área de estudio y estaciones de muestreo en Bahía Matanchén, costa de Nayarit, México

collected by divers using 'sampling boxes' $(35$ x 35 x 20 $\mathrm{cm}, 24 \mathrm{~L}$ ) used to obtain a comparable content to the Van Veen grab. Special care was taken to collect the top $(0-5$ $\mathrm{cm}$ ) of the sediments in both cases.

\section{Physico-Chemical analysis}

The samples of the water column were collected using a Niskin-type water sampler (3 L). Temperature, salinity, and dissolved oxygen (DO) were measured utilizing a multiparameter instrument YSI Pro-2030 (YSI, Yellow Springs, $\mathrm{OH}$, USA). The $\mathrm{pH}$ was measured with a portable potentiometer Hi 98127 (Hanna Instruments, TX, USA). The dissolved nutrients [dissolved inorganic nitrogen DIN= ammonium $\left(\mathrm{NH}_{4}^{+}\right)+$nitrates $\left(\mathrm{NO}_{3}^{-}\right)+$nitrites $\left.\left(\mathrm{NO}_{2}^{-}\right)\right]$and soluble reactive phosphorus $\left(\mathrm{PO}_{4}^{3-}\right)$ ] were analyzed. For this purpose, the water samples were filtered using a nitrocellulose membrane filter with a pore size of $0,45 \mu \mathrm{m}$ (Millipore HA), and the nutrients were determined by colorimetric methods (Strickland \& Parsons 1972) with a spectrophotometer YSI 9100 (YSI, Yellow Springs, OH, USA). Chlorophyll 'a' (Chl-a) and water organic matter (WOM) were determined using the time series database Giovann by employing the superficial $(0$ and $10 \mathrm{~m})$ water samples only. These data were obtained in quarterly time series produced by the Aqua-Modis satellite with a maximum reading in the study area of $4 \mathrm{~km}$.
Granulometry was performed on the sediment samples using the Wentworth scale. The combustion method was used in determining the sediment organic matter (SOM) (Dell'Anno et al. 2002). The total nitrogen (TN) was obtained by the Kjeldhal method (AOAC 1985). The total phosphorus (TP) was evaluated in the dried samples, which were homogenized by grinding and digested with a mixture of concentrated perchloric and nitric acid (Sturgeon et al. 1982). The TP was determined colorimetrically as molybdate reactive phosphorus (Strickland \& Parsons 1972). In addition, we calculated the N:P ratio (nitrogen:phosphorus) for water and sediment.

\section{Statistical ANALYSis}

The data was grouped into four seasons according to the grouping of discriminant analysis (Fig. 5). The data were logarithmically transformed to create a normal distribution. Analysis of variance (ANOVA) was used to determine the overall significance of differences among samples and seasons on variations in physico-chemical parameters in waters and sediments. The post hoc Tukey's HSD test was applied to determine statistically significant differences $(P<0.05)$ following ANOVA. The effects of spatial and temporal variation were analyzed by cluster and discriminant analysis using Statistica 5.5 (Statsoft Inc. OK, USA) package software. 

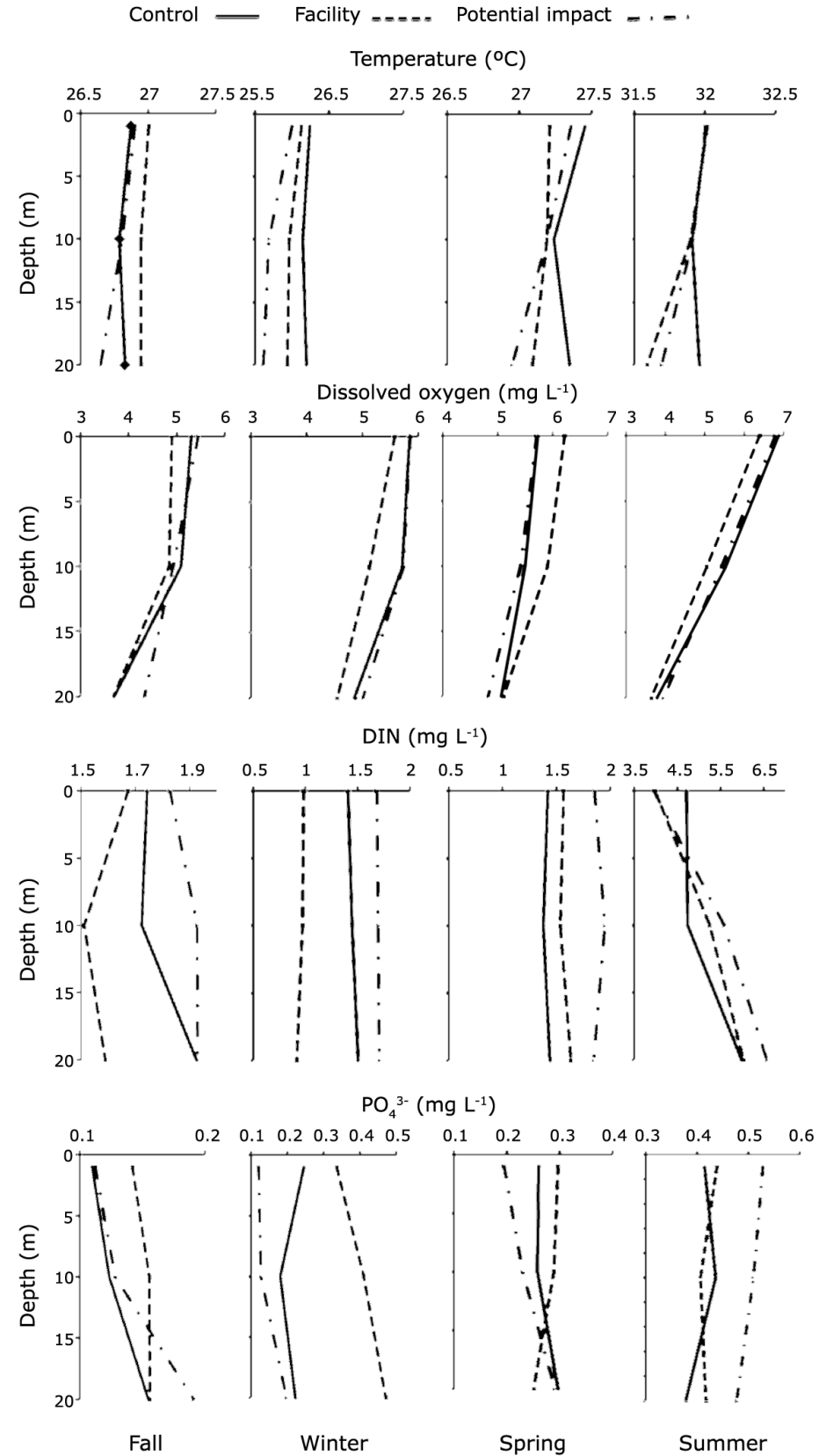

Figure 2. Temperature, dissolved oxygen, dissolved inorganic nitrogen (DIN) and phosphates $\left(\mathrm{PO}_{4}{ }^{3-}\right)$ in the water column at the control, facility and potential impact stations, for an annual cycle (2014-2015) / Temperatura, oxígeno disuelto, nitrógeno inorgánico disuelto (DIN) y fosfatos $\left(\mathrm{PO}_{4}{ }^{3-}\right)$ en la columna de agua en las estaciones de control, jaulas flotantes e impacto potencial para un ciclo anual (2014-2015) 


\section{Results}

\section{WATER COLUMN ANALYSIS}

No significant differences in water temperature, salinity, $\mathrm{pH}$, and dissolved oxygen were found between the facility, potential impact, and control stations, but there were seasonal variations in these parameters (Table 1).

Generally, a relationship was found between the rainy season and runoff with higher current velocity, temperature, ammonia, nitrites, nitrates, phosphates, Chl- $a$, and lower $\mathrm{pH}$. Specifically, the current velocity $\left(8.1\right.$ and $\left.13.4 \mathrm{~cm} \mathrm{~s}^{-1}\right)$ and rainfall (50 and $278.4 \mathrm{~mm}$ ) were significantly lower in the fall and higher during the summer season, respectively. The lowest temperature was recorded in winter $\left(26^{\circ} \mathrm{C}\right)$ and the highest in summer $\left(31.9^{\circ} \mathrm{C}\right)$ at the facility and potential impact station, respectively. There were no significant differences in the temperature of the water column. The highest salinity $\left(38.0 \mathrm{~g} \mathrm{~L}^{-1}\right)$ was recorded in spring and the lowest in fall (34.6-34.8 $\left.\mathrm{g} \mathrm{L}^{-1}\right)$. The lowest $\mathrm{pH}$ (7.4-7.6) and DO (4.5-5.0 $\left.\mathrm{mg} \mathrm{L}^{-1}\right)$ were recorded in summer and fall, respectively. The DO concentrations in the water were lower and significantly different at the facility (4.5 $\left.\mathrm{mg} \mathrm{L}^{-1}\right)$ in fall season as compared to other seasons (Table 1). Regarding the concentration of DO in the water column ( 0 to $20 \mathrm{~m}$ ), the greatest difference $(6.5$ to $3.7 \mathrm{mg} \mathrm{L}^{-1}$ ) was found in winter. The greatest variation of nutrients was measured at the facility in the fall and winter seasons, and in the potential impact stations during the spring and summer ones. In general, the highest concentration of nitrates $\left(1.92 \mathrm{mg} \mathrm{L}^{-1}\right)$ was found in the potential impact stations. Differences in the vertical

Table 1. Environmental parameters of the water column by season of the year in the sea cage fish farm in control (C), Facility (FA) and potential impact (PI) stations / Parámetros ambientales de la columna de agua por época del año en la granja de peces de jaulas flotantes en las estaciones de control (C), jaulas flotantes (FA) e impacto potencial (PI)

\begin{tabular}{|c|c|c|c|c|c|c|}
\hline \multirow{2}{*}{ Parameter } & \multicolumn{3}{|c|}{ Fall } & \multicolumn{3}{|c|}{ Winter } \\
\hline & $\mathrm{C}$ & FA & PI & $\mathrm{C}$ & FA & PI \\
\hline Current velocity $\left(\mathrm{cm} \mathrm{s}^{-1}\right)$ & $8.1 \pm 1.8^{\mathrm{c}}$ & $8.1 \pm 1.8^{\mathrm{c}}$ & $8.1 \pm 1.8^{\mathrm{c}}$ & $9.7 \pm 2.6^{\mathrm{b}}$ & $9.7 \pm 2.6^{\mathrm{b}}$ & $9.7 \pm 2.6^{\mathrm{b}}$ \\
\hline Rainfall $(\mathrm{mm})$ & $50.0 \pm 39.3^{b}$ & $50.0 \pm 39.3^{b}$ & $50.0 \pm 39.3^{b}$ & $41.5 \pm 33.9^{b}$ & $41.5 \pm 33.9^{b}$ & $41.5 \pm 33.9^{\mathrm{b}}$ \\
\hline Temperature $\left({ }^{\circ} \mathrm{C}\right)$ & $26.8 \pm 3.3^{\mathrm{b}}$ & $26.9 \pm 3.4^{\mathrm{b}}$ & $26.8 \pm 3.3^{\mathrm{b}}$ & $26.2 \pm 0.0^{\mathrm{b}}$ & $26.0 \pm 0.3^{\mathrm{b}}$ & $26.8 \pm 0.3^{\mathrm{b}}$ \\
\hline Salinity & $34.8 \pm 1.9^{\mathrm{a}}$ & $34.7 \pm 2.3^{\mathrm{a}}$ & $34.6 \pm 2.4^{\mathrm{a}}$ & $35.9 \pm 0.1^{\mathrm{a}}$ & $36.0 \pm 0.1^{\mathrm{a}}$ & $36.0 \pm 0.1^{\mathrm{a}}$ \\
\hline $\mathrm{pH}$ & $8.0 \pm 0.4^{\mathrm{a}}$ & $8.0 \pm 0.5^{\mathrm{a}}$ & $8.1 \pm 0.3^{\mathrm{a}}$ & $8.0 \pm 0.1^{\mathrm{a}}$ & $7.8 \pm 0.2^{\mathrm{a}}$ & $7.8 \pm 0.1^{\mathrm{a}}$ \\
\hline $\mathrm{DO}\left(\mathrm{mg} \mathrm{L}^{-1}\right)$ & $4.6 \pm 1.0^{b}$ & $4.5 \pm 0.6^{b}$ & $5.0 \pm 0.6^{b}$ & $5.5 \pm 0.4^{\mathrm{a}}$ & $5.1 \pm 0.4^{\mathrm{a}}$ & $5.5 \pm 0.8^{\mathrm{a}}$ \\
\hline Ammonium $\left(\mathrm{mg} \mathrm{L}^{-1}\right)$ & $0.56 \pm 0.20^{\mathrm{b}}$ & $0.50 \pm 0.27^{\mathrm{b}}$ & $0.61 \pm 0.03^{b}$ & $0.48 \pm 0.18^{\mathrm{b}}$ & $0.24 \pm 0.18^{\mathrm{c}}$ & $0.59 \pm 0.22^{b}$ \\
\hline Nitrite $\left(\mathrm{mg} \mathrm{L}^{-1}\right)$ & $0.10 \pm 0.05^{\mathrm{b}}$ & $0.08 \pm 0.06^{\mathrm{b}}$ & $0.10 \pm 0.06^{\mathrm{b}}$ & $0.13 \pm 0.01^{b}$ & $0.08 \pm 0.05^{\mathrm{b}}$ & $0.15 \pm 0.02^{\mathrm{b}}$ \\
\hline Nitrate $\left(\mathrm{mg} \mathrm{L}^{-1}\right)$ & $1.14 \pm 0.04^{b}$ & $1.02 \pm 0.07^{\mathrm{b}}$ & $1.19 \pm 0.02^{\mathrm{b}}$ & $0.84 \pm 0.30^{c}$ & $0.64 \pm 0.41^{\mathrm{d}}$ & $0.96 \pm 0.24^{\mathrm{c}}$ \\
\hline Phosphates $\left(\mathrm{mg} \mathrm{L}^{-1}\right)$ & $0.13 \pm 0.09^{\mathrm{c}}$ & $0.15 \pm 0.07^{\mathrm{c}}$ & $0.14 \pm 0.07^{\mathrm{c}}$ & $0.22 \pm 0.04^{\text {b.c }}$ & $0.18 \pm 0.07^{\mathrm{c}}$ & $0.15 \pm 0.06^{\mathrm{c}}$ \\
\hline OMW $\left(\mathrm{mg} \mathrm{L}^{-1}\right)$ & $0.59 \pm 0.36^{\mathrm{a}}$ & $0.59 \pm 0.36^{\mathrm{a}}$ & $0.59 \pm 0.36^{\mathrm{a}}$ & $0.54 \pm 0.32^{\mathrm{c}}$ & $0.54 \pm 0.32^{\mathrm{c}}$ & $0.54 \pm 0.32^{\mathrm{c}}$ \\
\hline $\mathrm{N}: \mathrm{P}$ & $37.8 \pm 11.2^{\mathrm{a}}$ & $29.1 \pm 7.8^{\mathrm{a}}$ & $37.5 \pm 10.6^{\mathrm{a}}$ & $18.6 \pm 4.5^{b}$ & $13.4 \pm 2.9^{\mathrm{c}}$ & $32.6 \pm 9.6^{\mathrm{a}}$ \\
\hline \multirow[t]{2}{*}{ Chl- $a\left(\mathrm{mg} \mathrm{m}^{-3}\right)$} & $7.1 \pm 4.2^{\mathrm{b}}$ & $7.1 \pm 4.2^{\mathrm{b}}$ & $7.1 \pm 4.2^{\mathrm{b}}$ & $5.2 \pm 2.3^{\mathrm{c}}$ & $5.2 \pm 2.3^{\mathrm{c}}$ & $5.2 \pm 2.3^{\mathrm{c}}$ \\
\hline & \multicolumn{3}{|c|}{ Spring } & \multicolumn{3}{|c|}{ Summer } \\
\hline Parameter & $\mathrm{C}$ & FA & PI & $\mathrm{C}$ & FA & PI \\
\hline Current velocity $\left(\mathrm{cm} \mathrm{s}^{-1}\right)$ & $10.6 \pm 1.9^{\mathrm{b}}$ & $10.6 \pm 1.8^{\mathrm{b}}$ & $10.6 \pm 1.8^{\mathrm{b}}$ & $13.4 \pm 1.8^{\mathrm{a}}$ & $13.4 \pm 1.8^{\mathrm{a}}$ & $13.4 \pm 1.82^{\mathrm{a}}$ \\
\hline Rainfall (mm) & $13.7 \pm 13.9^{c}$ & $13.7 \pm 13.9^{\mathrm{c}}$ & $13.7 \pm 13.9^{\mathrm{c}}$ & $278.4 \pm 228.8^{\mathrm{a}}$ & $278.4 \pm 228.8^{\mathrm{a}}$ & $278.4 \pm 228.8^{\mathrm{a}}$ \\
\hline Temperature $\left({ }^{\circ} \mathrm{C}\right)$ & $27.3 \pm 0.9^{\mathrm{b}}$ & $27.2 \pm 0.8^{\mathrm{b}}$ & $27.2 \pm 1.1^{\mathrm{b}}$ & $31.9 \pm 0.2^{\mathrm{a}}$ & $31.8 \pm 0.3^{\mathrm{a}}$ & $31.9 \pm 0.2^{\mathrm{a}}$ \\
\hline Salinity & $38.0 \pm 0.1^{\mathrm{a}}$ & $38.0 \pm 0.1^{\mathrm{a}}$ & $38.0 \pm 0.1^{\mathrm{a}}$ & $35.3 \pm 0.6^{\mathrm{a}}$ & $35.3 \pm 0.6^{\mathrm{a}}$ & $35.3 \pm 0.6^{\mathrm{a}}$ \\
\hline $\mathrm{pH}$ & $7.6 \pm 0.3^{\mathrm{a}, \mathrm{b}}$ & $7.5 \pm 0.3^{\mathrm{a}, \mathrm{b}}$ & $7.6 \pm 0.3^{\mathrm{a}, \mathrm{b}}$ & $7.4 \pm 0.1^{b}$ & $7.4 \pm 0.1^{\mathrm{b}}$ & $7.4 \pm 0.2^{\mathrm{b}}$ \\
\hline $\mathrm{DO}\left(\mathrm{mg} \mathrm{L}^{-1}\right)$ & $5.5 \pm 0.7^{\mathrm{a}}$ & $5.7 \pm 0.1^{\mathrm{a}}$ & $5.3 \pm 0.1^{\mathrm{a}}$ & $5.8 \pm 0.1^{\mathrm{a}}$ & $5.3 \pm 0.7^{\mathrm{a}}$ & $5.8 \pm 0.2^{\mathrm{a}}$ \\
\hline Ammonium $\left(\mathrm{mg} \mathrm{L}^{-1}\right)$ & $0.37 \pm 0.24^{\mathrm{c}}$ & $0.34 \pm 0.12^{\mathrm{c}}$ & $0.55 \pm 0.34^{\mathrm{b}}$ & $1.31 \pm 0.12^{\mathrm{a}}$ & $1.26 \pm 0.06^{\mathrm{a}}$ & $1.25 \pm 0.17^{\mathrm{a}}$ \\
\hline Nitrite $\left(\mathrm{mg} \mathrm{L}^{-1}\right)$ & $0.10 \pm 0.01^{b}$ & $0.04 \pm 0.02^{\mathrm{c}}$ & $0.07 \pm 0.03^{\mathrm{c}}$ & $0.19 \pm 0.10^{\mathrm{a}}$ & $0.21 \pm 0.03^{\mathrm{a}}$ & $0.27 \pm 0.18^{\mathrm{a}}$ \\
\hline Nitrate $\left(\mathrm{mg} \mathrm{L}^{-1}\right)$ & $0.95 \pm 0.35^{\mathrm{c}}$ & $1.21 \pm 0.19^{\mathrm{b}}$ & $1.26 \pm 0.70^{\mathrm{b}}$ & $1.65 \pm 0.01^{\mathrm{a}}$ & $1.60 \pm 0.08^{\mathrm{a}}$ & $1.92 \pm 0.07^{\mathrm{a}}$ \\
\hline Phosphates $\left(\mathrm{mg} \mathrm{L}^{-1}\right)$ & $0.27 \pm 0.12^{\mathrm{b}}$ & $0.24 \pm 0.09^{\mathrm{b}}$ & $0.28 \pm 0.11^{\mathrm{b}}$ & $0.41 \pm 0.02^{\mathrm{a}}$ & $0.42 \pm 0.05^{\mathrm{a}}$ & $0.51 \pm 0.03^{\mathrm{a}}$ \\
\hline OMW $\left(\mathrm{mg} \mathrm{L}^{-1}\right)$ & $0.49 \pm 0.31^{\mathrm{d}}$ & $0.49 \pm 0.31^{\mathrm{d}}$ & $0.49 \pm 0.31^{\mathrm{d}}$ & $0.57 \pm 0.21^{\mathrm{b}}$ & $0.57 \pm 0.21^{\mathrm{b}}$ & $0.57 \pm 0.21^{b}$ \\
\hline $\mathrm{N}: \mathrm{P}$ & $13.4 \pm 3.8^{\mathrm{c}}$ & $15.5 \pm 4.0^{\mathrm{c}}$ & $17.8 \pm 4.9^{\mathrm{b}, \mathrm{c}}$ & $23.9 \pm 3.9^{b}$ & $22.7 \pm 4.2^{\mathrm{b}}$ & $19.8 \pm 4.1^{\mathrm{b}}$ \\
\hline Chl- $a\left(\mathrm{mg} \mathrm{m}^{-3}\right)$ & $4.7 \pm 1.7^{\mathrm{d}}$ & $4.7 \pm 1.7^{\mathrm{d}}$ & $4.7 \pm 1.7^{\mathrm{d}}$ & $7.6 \pm 1.5^{\mathrm{a}}$ & $7.6 \pm 1.5^{\mathrm{a}}$ & $7.6 \pm 1.5^{\mathrm{a}}$ \\
\hline
\end{tabular}

The results are the mean \pm standard deviation; different superscripts in rows are significantly different $(P<0.05)$ 
profiles of DIN across the water column were found. The vertical profiles for $\mathrm{PO}_{4}{ }^{3-}$ distribution displayed significantly higher concentrations in the facility in the winter and in the potential impact stations during the summer. The significantly lower concentrations of WOM and Chl- $a$ were recorded to be $0.49 \mathrm{mg} \mathrm{L}^{-1}$ and $4.70 \mathrm{mg} \mathrm{m}^{-3}$, respectively in the spring season. It was also found that the highest standard deviation of the parameters of water (temperature, salinity, $\mathrm{pH}, \mathrm{DO}, \mathrm{PO}_{4}^{3-}, \mathrm{Chl}-a$ and $\mathrm{N}: \mathrm{P}$ ratio) were recorded during fall. Our findings indicated that the high levels of ammonium (1.26-1.31 $\left.\mathrm{mg} \mathrm{L}^{-1}\right)$, nitrite $(0.19$ $\left.0.27 \mathrm{mg} \mathrm{L}^{-1}\right)$, nitrate $\left(1.60-1.92 \mathrm{mg} \mathrm{L}^{-1}\right)$, phosphates $(0.41$ $\left.0.51 \mathrm{mg} \mathrm{L}^{-1}\right)$, and Chl- $a\left(7.6 \mathrm{mg} \mathrm{m}^{-3}\right)$ were present in summer. The N:P ratio in the water showed its highest values (29.1 to 37.8 ) and the greatest variability in fall and its lowest values (13.4 to 17.8$)$ in spring.

\section{SEDiment ANALYSIS}

The floating sea-cage facility, potential impact and control stations were characterized by sandy sediments. The highest percentage of clay was found in the control station as compared to the facility and potential impact station, and a greater proportion of silt was identified in the control station relative to the facility and potential impact station (Table 2). The highest variability of clay content was found in the potential impact station. Significant differences in TP and SOM content were found between the sediment samples from the facility and control station. The greatest variability of SOM and NT was recorded in winter. The lowest current speed (fall season) was significantly associated with the highest concentration of WOM, TN, and SOM. The N:P ratio in the sediment had the highest values (8.8 to 10.5$)$ in fall, the lowest (3.6 to 6.1) in spring, and the greatest variability in winter.

Table 2. Sediment parameters (\%) by season of the year in the sea cage fish farm in control (C), facility (FA) and potential impact (PI) stations / Parámetros del sedimento (\%) por época del año en la granja de peces de jaulas flotantes en las estaciones de control (C), jaulas flotantes (FA) e impacto potencial (PI)

\begin{tabular}{|c|c|c|c|c|c|c|}
\hline \multirow{2}{*}{ Parameter } & \multicolumn{3}{|c|}{ Fall } & \multicolumn{3}{|c|}{ Winter } \\
\hline & $\mathrm{C}$ & FA & PI & $\mathrm{C}$ & FA & PI \\
\hline Sand & $61.2 \pm 2.9^{\mathrm{a}}$ & $53.6 \pm 5.2^{\mathrm{b}}$ & $69.1 \pm 3.9^{\mathrm{a}}$ & $47.5 \pm 9.7^{\mathrm{b}}$ & $51.7 \pm 5.9^{\mathrm{b}}$ & $58.0 \pm 5.3^{\mathrm{a}}$ \\
\hline Silt & $26.3 \pm 9.5^{b}$ & $30.6 \pm 6.7^{\mathrm{a}}$ & $22.9 \pm 9.4^{b}$ & $32.9 \pm 10.2^{\mathrm{a}}$ & $\mathrm{a} \quad 31.1 \pm 4.9^{\mathrm{a}}$ & $25.7 \pm 5.8^{\mathrm{b}}$ \\
\hline Clay & $14.5 \pm 3.7^{b}$ & $15.9 \pm 3.4^{\mathrm{b}}$ & $12.4 \pm 4.8^{\mathrm{b}}$ & $20.4 \pm 0.5^{\mathrm{a}}$ & $18.9 \pm 1.2^{\mathrm{a}}$ & $18.7 \pm 1.5^{\mathrm{a}}$ \\
\hline $\mathrm{TN}$ & $0.26 \pm 0.06^{\mathrm{a}}$ & $0.21 \pm 0.07^{\mathrm{a}}$ & $0.19 \pm 0.01^{\mathrm{a}}$ & $0.12 \pm 0.10^{\mathrm{b}}$ & b $0.12 \pm 0.07^{\mathrm{b}}$ & $0.08 \pm 0.07^{\mathrm{c}}$ \\
\hline $\mathrm{TP}$ & $0.26 \pm 0.04^{\mathrm{b}}$ & $0.19 \pm 0.02^{b}$ & $0.16 \pm 0.02^{b}$ & $0.28 \pm 0.02^{b}$ & b $0.17 \pm 0.02^{b}$ & $0.14 \pm 0.02^{\mathrm{c}}$ \\
\hline $\mathrm{N}: \mathrm{P}$ & $8.88 \pm 1.68^{\mathrm{a}}$ & $9.81 \pm 1.92^{\mathrm{a}}$ & $10.54 \pm 0.81^{\mathrm{a}}$ & $3.80 \pm 1.37^{\mathrm{c}}$ & c $6.26 \pm 2.18^{\mathrm{b}}$ & $5.07 \pm 2.06^{\mathrm{b}}$ \\
\hline OMS & $8.7 \pm 2.2^{\mathrm{a}}$ & $6.1 \pm 0.2^{\mathrm{a}}$ & $6.4 \pm 0.3^{\mathrm{a}}$ & $4.2 \pm 3.9^{\mathrm{b}}$ & $2.9 \pm 2.3^{\mathrm{b}}$ & $3.0 \pm 2.9^{\mathrm{b}}$ \\
\hline \multirow{2}{*}{ Parameter } & \multicolumn{3}{|c|}{ Spring } & \multicolumn{3}{|c|}{ Summer } \\
\hline & $\mathrm{C}$ & FA & PI & $\mathrm{C}$ & FA & PI \\
\hline Sand & $57.0 \pm 1$ & $59.4 \pm 8.0^{\mathrm{a}}$ & $01.5 \pm=$ & $60.3 \pm 3.1^{\mathrm{a}}$ & $58.9 \pm 1.5$ & $61.2 \pm 1.1^{\mathrm{a}}$ \\
\hline Silt & $32.2 \pm 9.9^{\mathrm{a}}$ & $31.5 \pm 6.6^{\mathrm{a}}$ & $26.8 \pm 3.6^{\mathrm{a}, \mathrm{b}}$ & $27.4 \pm 10.2^{\mathrm{a}}$ & $31.5 \pm 6.1^{\mathrm{a}}$ & $25.7 \pm 6.0^{\mathrm{b}}$ \\
\hline Clay & $11.1 \pm 4.1^{\mathrm{b}}$ & $9.5 \pm 1.0^{\mathrm{c}}$ & $9.3 \pm 3.8^{c}$ & $9.3 \pm 1.2^{\mathrm{c}}$ & $7.5 \pm 2.8^{d}$ & $8.9 \pm 3.5^{c}$ \\
\hline $\mathrm{TN}$ & $0.12 \pm 0.05^{\mathrm{b}}$ & $0.12 \pm 0.01^{\mathrm{b}}$ & $0.11 \pm 0.06^{\mathrm{b}, \mathrm{c}}$ & $0.14 \pm 0.02^{\mathrm{b}}$ & $0.15 \pm 0.02^{\mathrm{b}}$ & $0.15 \pm 0.04^{\mathrm{b}}$ \\
\hline TP & $0.30 \pm 0.03^{\mathrm{a}}$ & $0.19 \pm 0.02^{\mathrm{b}}$ & $0.16 \pm 0.02^{\mathrm{b}}$ & $0.26 \pm 0.04^{\mathrm{b}}$ & $0.18 \pm 0.01^{\mathrm{b}}$ & $0.16 \pm 0.02^{\mathrm{b}, \mathrm{c}}$ \\
\hline $\mathrm{N}: \mathrm{P}$ & $3.55 \pm 0.86^{\mathrm{c}}$ & $5.61 \pm 0.58^{\mathrm{b}}$ & $6.10 \pm 2.09^{b}$ & $4.78 \pm 0.72^{\mathrm{c}}$ & $7.40 \pm 0.67^{\mathrm{a}, \mathrm{b}}$ & $8.32 \pm 1.61^{\mathrm{a}}$ \\
\hline OMS & $3.4 \pm 0.9^{\mathrm{b}}$ & $2.8 \pm 0.9^{b}$ & $3.0 \pm 1.2^{b}$ & $4.8 \pm 0.6^{b}$ & $4.2 \pm 1.5^{\mathrm{b}}$ & $5.1 \pm 1.3^{a . b}$ \\
\hline
\end{tabular}

The results are the mean \pm standard deviation; different superscripts in rows are significantly different $(P<0.05)$ 
The cluster analysis of the water and sediment parameters revealed two groups: the water parcel represented by salinity and temperature and the interaction of the physico-chemical parameters of water and sediment (Fig. 3). Significant relationships were found between the clay and the organic matter and nutrients of the sediment, as well as between the clay and the phosphorus and nitrites of the water column.

The discriminant analysis showed the differentiation of three different groups of stations (Fig. 4), and a closer relationship between facility and potential impact stations throughout the year. In addition, our analysis differentiated seasonal characteristics based on the water quality and sediment samples of the facility, potential impact, and control stations. Environmental conditions could be grouped into 4 seasonal clusters, corresponding to the months and predominant seasons of the year: October to February (fall-winter), March to May (spring), June to August (summer), and the last in September (Fig. 5). The main parameters that were found to distinguish the groups in the discriminant analysis were temperature, the rainy season, and current velocity.

\section{Discussion}

The detection and explanation of the physico-chemical dynamics of sea-cage fish farms require the knowledge of water-column dynamics to explain the complex changing aspects of the underlying sediment (Sara 2007). The dominant current direction in this study area was found to be southeast, which minimizes the possibility of influencing the control station by wastes from sea-cage fish farms. The current velocities and heights of the water column during the study periods ranged from 8.1 to 13.4 $\mathrm{cm} \mathrm{s}^{-1}$ and 18 to $20 \mathrm{~m}$, respectively. These speeds were within the magnitude range recorded in sea-cage fish farms in areas of high aquaculture production (Morata et al. 2015, Price et al. 2015, Tomassetti et al. 2016). In general terms, the literature has demonstrated that good management of marine areas recommends placing the cages in areas of mean current $>7 \mathrm{~cm} \mathrm{~s}^{-1}$ (Price et al. 2015) and with water depth that is at least twice that of the floating cage (Belle \& Nash 2008). These guidelines help promote the dispersion and dilution of the nutrients for natural assimilation.

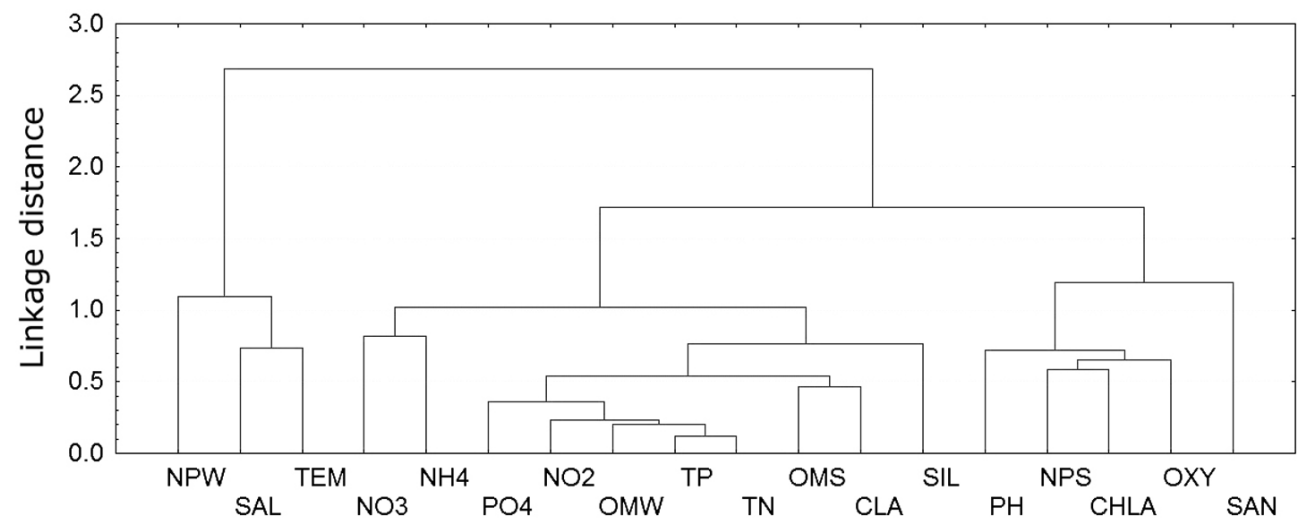

Figure 3. Cluster analysis of water column and sediment parameters. SAL, salinity; TEM, temperature; PO4, phosphate; NO2, nitrite; OMW, organic matter in water; OMS, organic matter in sediment; TP, total phosphate; TN, total nitrogen; CLA, clay; NO2, nitrate; NH4, ammonium; SIL, silt; PH, pH; OXY, dissolved oxygen; SAN, sand; CHLA, Chl- $a$; NPW, N:P ratio in water; NPS, N:P ratio in sediment / Análisis de clúster de los parámetros de la columna de agua y sedimento 


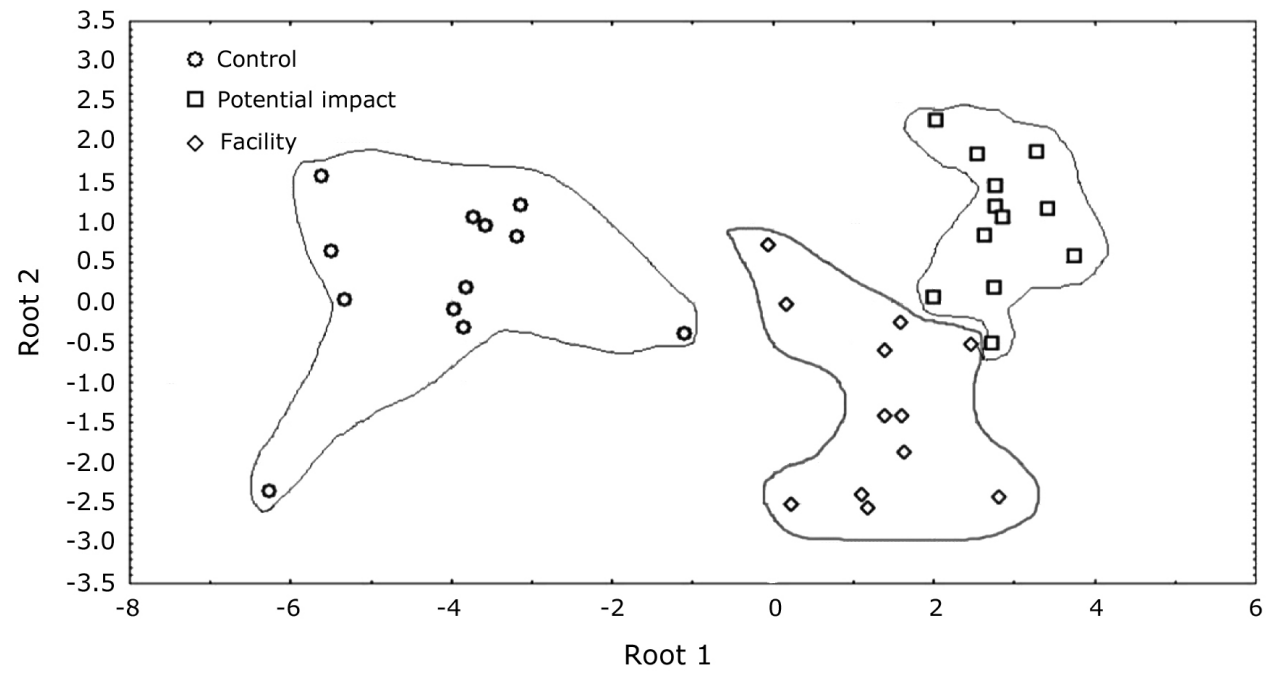

Figure 4. Discriminant analysis of water column and sediment parameters sample stations, for an annual cycle (2014-2015) / Análisis de discriminante de los parámetros de las estaciones de la columna de agua y sedimento, de un ciclo anual (2014-2015)

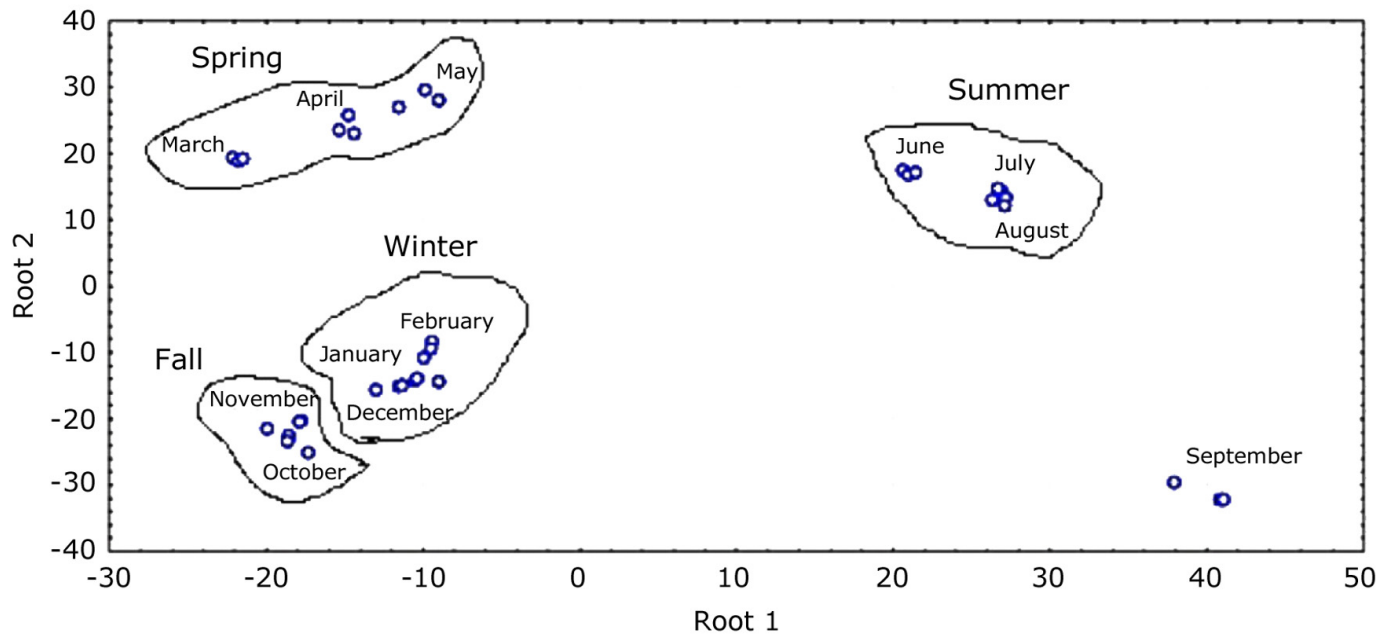

Figure 5. Discriminant analysis of water column and sediment parameters for an annual cycle (2014-2015) / Análisis de discriminante mensual de los parámetros de las estaciones de la columna de agua y sedimento, durante un ciclo anual (2014-2015) 
No thermocline was observed throughout the year (Fig. 2). The DO concentrations ( 4.5 to $5.7 \mathrm{mg} \mathrm{L}^{-1}$ ) were higher than the farm's critical value $\left(3.7 \mathrm{mg} \mathrm{L}^{-1}\right)$ for sustainable aquaculture production (Abo \& Yokayama 2007). The lower DO values were observed in the fall season, due to the high temperature and greater WOM concentration (Fig. 2). The DO concentration was generally lower in fall, winter, and summer seasons at the facility relative to the control and potential impact stations. The lowest DO was determined in the bottom layer (Fig. 2). This could be an indication of higher oxygen consumption directly by decomposition of settled particulate matter and/or fish as well as oxidation of their metabolic products. These results are similar to those reported under the cages of Dicentrarchus labrax and Sparus aurata farms in the Mediterranean Sea (La Rossa et al. 2002) and salmon farms in Chile (Soto \& Norambuena 2004). The highest registered concentrations of DIN in the water column were due to $\mathrm{NO}_{3}^{-}, \mathrm{NH}_{4}^{+}$, and $\mathrm{NO}_{2}^{-}$; in order of importance. The highest concentration of $\mathrm{NO}_{3}^{-}$was found probably due to the rapid oxidation of $\mathrm{NH}_{4}^{+}$and $\mathrm{NO}_{2}^{-}$for oxygenation of the water column (Dosdat 2000). Generally, lower concentrations of DIN were measured from fall to spring seasons relative to those measured in summer. This reflects the dynamics caused by summer stratification of the water column due to increased temperature and irradiance (Maldonado et al. 2005). Moreover, differences between the facility and control stations were observed during the winter season for the concentrations of $\mathrm{PO}_{4}{ }^{3-}$ in the water column. This can be attributed to the presence of phosphorus compounds and SOM in the sediment (Table 2). Some previous studies on small-scale sea-cage fish farms have not reported differences for any of the parameters measured in the water column (oxygen or nutrients) and control station (Kaymakci-Basaran et al. 2010). Sea-cage fish farms are expected to produce waste characterized in large proportions of $\mathrm{N}$ and $\mathrm{P}$ in solute form released into the water column. There may be concerns about increased primary production and other trophic impacts near farms. However, some studies of plankton in the areas of influence of fish farming have shown no significant differences between cage sites and controls (Pitta et al. 1999). In some studies, only seasonal differences have been evidenced around the cage systems (Price et al. 2015), in a similar manner to the results here. However, differences between facility and control stations have often been detected in bays with lesser circulation and in industrial-scale cage fish farms (La Rossa et al. 2002, Yucel-Gier et al. 2007, Morata et al. 2015).

It is well documented that most of the nitrogen in the water column was found in dissolved form, and even the low particulate nitrogen output (Cho \& Bureau 2001) underwent fast biochemical degradation and reincorporated into the water column once it settles down (Cromey et al. 2002). On the other hand, the higher values observed in all stations in our study site might have been influenced by the nearby floodway stream and domestic sewage loads, which continuously emit fine sediments (nutrients from agricultural by-products). It is also known that in the water column of the study area, ammonia is quickly oxidized to nitrate, which is less toxic (Dosdat 2000). Our results have shown that increased nutrients (DIN) only occur in the lower part of the water column, mainly in summer (Fig. 2). This is likely a result of the periodic influence of the Naranjo River, which discharges in the Matanchén Bay where the fish cages are located, increasing the sedimentation rate of particulate organic materials in this area. Increased benthic fluxes of nutrients at the sea-cage fish farm under riverine influence have been observed in cage fish farms in other areas of the world (Baric et al. 2002, Matijevic et al. 2009). It was found that the water column variation is due to nutrient runoff along the continental water and to the changes in the DIN and $\mathrm{PO}_{4}^{3-}$ ratios induced by anthropogenic activities. This seasonal incidence has been reported for other nearshore sea cage systems in Mediterranean waters (Vila et al. 2001, Olivos et al.2002). This could be due to several factors. Specifically, the hydrodynamics of the study area might have contributed to the dilution and dispersion of total solids and nutrients supplied by the shore. However, it is challenging to assess whether the water quality is being affected by the sea cages in the area of influence and at longer time scales using the present information (Grant 2010). This is further complicated by the anthropogenically-derived nutrients in the coastal marine water, making it difficult to quantify the proportion of each of the sources including aquaculture (Price et al. 2015). The observed changes of parameter in the water column were predominantly due to the seasonal weather patterns of the Matanchén Bay, since they occurred at the facility, potential impact, and control stations. Spatial and temporal distribution of nutrients and their ratios indicated the weak influence of the floating sea-cage fish 
farm on the dissolved nutrient pool. However, many authors have demonstrated that the water column can also record some effects on short- and medium-temporal terms (Handerson et al. 1997). In this study, these effects were not detected, most likely due to by the low level of production of snapper and tilapia (30 ton year-1). The maximum concentration of Chl- $a$ was $7.6 \mathrm{mg} \mathrm{m}^{-3}$ in summer, which was below the recommended maximum of $10 \mathrm{mg} \mathrm{m}^{-3}$ (Pitta et al. 1999) as an environmental quality standard to avoid eutrophication, particularly for the coastal zone (Yucel-Gier et al. 2007).

Small differences in particle size were observed between the different stations during the annual cycle (Table 2). There was a slight increase of the finest fraction in fall and winter seasons. The presence of floating cages did not appear to result in a decrease in water current velocity, leading to the settlement of bigger particles close to the system, as was reported at a marine cage farm in Gran Canaria Island (Molina-Domínguez et al. 2001). The $\mathrm{OM}$ and TP concentrations in the sediments observed in other sea-cage fish farm were similar to those measured in this study (Karakassis et al. 1998, Porrello et al. 2005, Morata et al. 2015). The highest OMS content was found at fall season, due to the higher rates of organic matter deposition from terrigenous contributions probably associated to Naranjo River by runoff effects for the rainy season (Castillo-Vargasmachuca et al. 2012). This input of organic matter at the water column and sediment surface increases the oxygen consumption due to the increased metabolism of the system (Morata et al. 2012). Organic matter in surface sediment is an important source of food for benthic fauna (Tomassetti et al. 2016). However, an overabundance of OM may lead to reduction in species richness, abundance and biomass, and the remediation of enriched sediments may take several years (Pereira et al. 2004). The TP concentrations recorded in the present study were relatively high in the sediment (Karakassis et al. 1998, 1999, Porrello et al. 2005). The results of this study suggest that no detectable accumulation of solid particulate wastes, as well as lower organic enrichment from the marine cage farm, had taken place after two years of operation. These findings were mainly because the current velocity contributes to the dispersion of nutrients (Black \& McDougall 2002), thus avoiding the undesirable effects of organic sediment accumulation (Yokoyama 2003). In addition, the distance between the sea-cage floor and the bottom of the sea $(12$ to $15 \mathrm{~m})$ facilitates waste dispersal (Porrello et al. 2005). It has generally been reported that the results of the effects on primary production resulting from eutrophication are highly variable (Price et al. 2015). Increased nutrient loading has little or no detectable impact in some places, and we conclude this was the case at this site during our study. However, it is convenient that in the summer (due to the increase of nutrients in the water column) the biomass of the farm is adjusted to reduce the environmental impacts and scaling up to industrial Aquaculture production could be harmful given that the site does have high concentration of nutrients in that season.

The molar N:P ratio for the water and sediment stations varied from 13.4 to 37.8 and 3.8 to 10.54 , respectively. The ratio in water was usually higher than the Redfield atomic ratio of 16:1 (Turner et al. 2006). In the sediment, it was below the Redfield ratio, which is indicative of nitrogenlimited sediment (Guildford et al. 2000) that has already been reported in the region for several coastal waters (Páez-Osuna et al. 2013). Phosphorus was limited in some stations during winter and summer, and in all stations throughout autumn seasons. This might be because the rain and ocean currents help in keeping the $\mathrm{TN}$ in surface ocean water, whereas phosphorus is lost as sedimentation (Páez-Osuna et al. 2013).

The most sensitive parameters in our study were found to be N:P, Chl- $a$, ammonium and phosphates in the water, and clay, SOM, and N:P in the sediment. They showed significant changes related to the distance from the sea cages and the annual seasonal cycle (Fall-Winter and Spring-Summer). However, it is worth mentioning that although the measured concentrations clearly depict the influence of the fish farm especially on the sediments, their values were, in general, considerably lower than those reported in the related studies on sea-cage fish farms (Mantzavrakos et al. 2007, Fodelianakis et al. 2015, Samuelsen et al. 2015, Tomassetti et al. 2016). Few studies on the coasts of the Nayarit state have investigated the physical aspects (e.g., depth, latitude, current profile) of the cage farms floating in the sea, their management characteristics (e.g., cultured species, volume of cages, biomass, feeding rate) and water quality, or over repeated production cycles. Hence, additional research in this region of Mexico would be beneficial. It is considered necessary to study the biogeochemical processes induced by marine cage aquaculture (nutrients, food pellets, and dissolved oxygen) that can affect food web dynamics (Piroddi et al. 2011). 
In conclusion, monitoring the physical and chemical properties of the water column and sediments at a floating sea-cage fish farm in Matanchén Bay (SE of the mouth of Gulf of California) revealed changes regarding the natural state of the environment. A minor influence of fish aquaculture on the water quality and sediments was demonstrated. Seasonal changes were also observed in terms of increased nitrate and phosphate concentrations in the water column, and clay and OMS in the sediment. The current ( $\left.>5 \mathrm{~cm} \mathrm{~s}^{-1}\right)$, depth (12 to $15 \mathrm{~m}$ beneath cages), DO (mean minimum $4.5 \mathrm{mg} \mathrm{L}^{-1}$ ), and low level of fish production (30 ton year-1) contribute to a rapid turnover of the organic biodeposits, which were transformed and diluted at a fast rate. However, it was found that at the beginning of the autumn season, the rate current attained the lowest value of the year $\left(8.1 \mathrm{~cm} \mathrm{~s}^{-1}\right)$ and the SOM concentrations (6.1 to $8.7 \%$ ) were the highest. Temporal changes observed for most of the variables show a typical seasonal pattern in all stations. The impact of farming on the water column must be further investigated in terms of continuous input of dissolved organic carbon and nutrients that increase the background levels, rather than as a process able to modify the natural seasonal variability. The comparative analysis of physico-chemical parameters of the water column and sediments in the cage fish farm showed that floating culture cages induced a lower disturbance in the open sea environment due to the relatively low level of production per operating area and the prevailing oceanographic conditions.

\section{LITERATURE CITED}

Abo K \& H Yokayama. 2007. Assimilative capacity of fish farm environments as determined by the benthic oxygen uptake rate: studies using a numerical model. Bulletin of National Fisheries Research and Development Agency 19: 79-87.

AOAC. 1985. Official methods of analysis of the Association of Analytical Chemistry, $14^{\text {th }}$ edition. Association of Official Analytical Chemists, Washington.

Baric A, G Kuspilic \& S Matijevic. 2002. Nutrient (N, P, Si) fluxes between marine sediments and water column in coastal and open Adriatic. Hydrobiologia 475: 151-159.

Belle SM \& CE Nash. 2008. Better management practices for net-pen aquaculture. In: Tucker CS \& JA Hargreaves (eds). Environmental best management practices for aquaculture, pp. 261-330. Wiley-Blackwell, Oxford.

Black KD \& N McDougall. 2002. Hydrography of four Mediterranean marine cage sites. Journal of Applied Ichthyology 18: 129-133.
Castillo-Vargasmachuca SG, JT Ponce-Palafox, E ChavezOrtiz \& JLArredondo-Figueroa. 2007. Effect of the initial stocking body weight on growth of spotted rose snapper Lutjanus guttatus (Steindachner, 1869) in marine floating cages. Revista de Biología Marina y Oceanografía 42(3): 261-267.

Castillo-Vargasmachuca SG, JT Ponce-Palafox, M GarcíaUlloa, JLArredondo-Figueroa, A Ruiz-Luna, E ChávezOrtiz \& AG Tacon. 2012. Effect of stocking density on growth performance and yield of subadult Pacific red snapper Lutjanus peru (Pisces: Lutjanidae), cultured in floating sea cages. North American Journal of Aquaculture 74: 413-418.

Cho CY \& DP Bureau. 2001. A review of diet formulation strategies and feeding systems to reduce excretory and feed wastes in aquaculture. Aquaculture Research 32(1): 349360 .

Cromey CJ, TD Nickell, KD Black, PG Provost \& CR Griffiths. 2002. Validation of fish farm waste resuspension model by use of a particulate tracer discharged from a point source in a coastal environment. Estuaries 25(5): 916-929.

Dell'Anno A, ML Mei, A Pusceddu \& R Danovaro. 2002. Assessing the trophic state and eutrophication of coastal marine systems: a new approach based on the biochemical composition of sediment organic matter. Marine Pollution Bulletin 44: 611-622.

Dosdat A. 2000. Environmental impact of aquaculture in the Mediterranean: nutritional and feeding aspects. Environmental Impact Assessment of Mediterranean Aquaculture Farms. Cahiers Options Méditerranéennes CIHEAM-FAO 55: 23-36.

Grant J. 2010. Coastal communities, participatory research, and far-field effects of aquaculture. Aquaculture Environment Interactions 1: 85-93.

Grigorakis K \& G Rigos. 2011. Aquaculture effects on environmental and public welfare the case of Mediterranean mariculture. Chemosphere 85: 899-919.

Grottum JA \& M Beveridge. 2007. A review of cage aquaculture: northern Europe. In: Halwart M, D Soto \& JR Arthur (eds). Cage aquaculture: regional reviews and global overview. FAO Fisheries Technical Papers 498: 126-154.

Guildford SJ, E Robert \& RE Hecky. 2000. Total nitrogen, total phosphorus, and nutrient limitation in lakes and oceans: Is there a common relationship. Limnology and Oceanography 45(6): 1213-1223.

Handerson RJ, DAM Forrest, KD Black \& MT Park. 1997. The lipid composition of sealoch sediments underlying salmon cages. Aquaculture 158: 69-83.

Hargrave BT, M Holmer \& CP Newcombe. 2008. Towards a classification of organic enrichment in marine sediments based on biogeochemical indicators. Marine Pollution Bulletin 56: 810-824. 
Holmer M. 2010. Environmental issues of fish farming in offshore waters: perspectives, concerns, and research needs. Aquaculture Environment Interactions 1: 57-70.

Holmer M, D Wildfish \& B Hargrave. 2005. Organic enrichment from marine finfish Aquaculture and effects on sediment biogeochemical processes. In: Hargrave BT (ed). Environmental effects of marine finfish aquaculture, $\mathrm{pp}$. 181-206. Springer, Berlin.

Karakassis I, E Hatziyanni, M Tsapakis \& W Plaiti. 1999. Benthic recovery following cessation of fish farming: a series of successes and catastrophes. Marine Ecology Progress Series 184: 205-218.

Karakassis I, M Tsapakis \& E Hatziyanni. 1998. Seasonal variability in sediment profiles beneath fish farm cages in the Mediterranean. Marine Ecology Progress Series 162: 243-252.

Kaymakci-Basaran A, M Aksu \& O Egemen. 2010. Impacts of the fish farms on the water column nutrient concentrations and accumulation of heavy metals in the sediments in the eastern Aegean Sea (Turkey). Environmental Monitoring and Assessment 162: 439-451.

La Rossa T, S Mirto, E Favaloro, B Savona, G Sará, R Danovaro \& A Mazzola. 2002. Impact on the water column biogeochemistry of a Mediterranean mussel and fish farm. Water Research 36: 713-721.

Maldonado M, MC Carmona, Y Echeverría \& A Riesgo. 2005. The environmental impact of Mediterranean cage fish farms at semi-exposed locations: does it need a reassessment? Helgoland Marine Research 59: 121-135.

Mantzavrakos E, M Kornaros, G Lyberatos \& P Kaspiris. 2007. Impacts of a marine fish farm in Argolikos Gulf (Greece) on the water column and the sediment. Desalination 210(1-3): 110-124.

Matijevic S, G Kuspilic, M Morovic, B Grbec, D Bogner, S Skejic \& J Veza. 2009. Physical and chemical properties of the water column and sediments at sea bass/sea bream farm in the middle Adriatic (Maslinova Bay). Acta Adriatica 50(1): 59-76.

Molina-Domínguez L, G López-Calero, JM VergaraMartín \& L Robaina-Robaina. 2001. A comparative study of sediments under a marine cage farm at Gran Canaria Island (Spain). Preliminary results. Aquaculture 192: 225231.

Morata T, J Sospedra, S Falco \& M Rodilla. 2012. Exchange of nutrients across the sediment-water interface below a marine fish farm of Sparus aurata in the Western Mediterranean Sea. Journal of Soils and Sediments 12: 6231632.

Morata T, S Falco, I Gadea, J Sospedra \& M Rodilla. 2015. Environmental effects of a marine fish farm of gilthead seabream (Sparus aurata) in the NW Mediterranean Sea on water column and sediment. Aquaculture Research 46: 5974.
Olivos A, MO Mas \& J Camp. 2002. Continental runoff of nutrients and their possible influence over stoichiometric ratios (DIN:P:Si) in the northeastern Mediterranean waters of Spain (Catalan Sea). Ciencias Marinas 2: 393-406.

Páez-Osuna F, A Piñón-Gimate, MJ Ochoa-Izaguirre, AC Ruiz-Fernández, G Ramírez-Reséndiz \& R AlonsoRodríguez. 2013. Dominance patterns in macroalgal and phytoplankton biomass under different nutrient loads in subtropical coastal lagoons of the SE Gulf of California. Marine Pollution Bulletin 77: 274-281.

Pereira PMF, KD Black, DS McLusky \& TD Nickell. 2004. Recovery of sediments after cessation of marine fish farm production. Aquaculture 235: 315-330.

Piroddi C, G Bearzi \& V Christensen. 2011. Marine open cage aquaculture in the eastern Mediterranean Sea: a new trophic resource for bottlenose dolphins. Marine Ecology Progress Series 440: 255-266.

Pitta P, I Karakassis, M Tsapakis \& S Zivanovic. 1999. Natural vs. mariculture induced variability in nutrients and plankton in the eastern Mediterranean. Hydrobiologia 391: 181-194.

Porrello S, P Tomassetti, L Manzueto, MG Finoia, E Persia, I Mercatali \& P Stipa. 2005. The influence of marine cages on the sediment chemistry in the western Mediterranean Sea. Aquaculture 249: 145-158.

Price C, KD Black, BT Hargrave \& JA Morris Jr. 2015. Marine cage culture and the environment: effects on water quality and primary production. Aquaculture Environment Interactions 6: 151-174.

Sanz-Lázaro C \& A Marín. 2011. Diversity patterns of benthic macrofauna caused by marine fish farming. Diversity 3: 176-199.

Sara G. 2007. Aquaculture effects on some physical and chemical properties of the water column: a meta-analysis. Chemical and Ecology 23: 251-262.

Soto D \& F Norambuena. 2004. Evaluation of salmon farming effects on marine systems in the inner seas of southern Chile: a large scale measurement experiment. Journal of Applied Ichthyology 20: 493-501.

Strickland JDH \& TR Parsons. 1972. A practical handbook of seawater analysis. Bulletin of the Fisheries Research Board of Canada 167: 1-310.

Sturgeon RE, JAH Desaulniers, SS Berman \& DS Russel. 1982. Determination of tract metals in estuarine sediments by graphite-furnace atomic absorption spectrometry. Analytica Chimica Acta 134: 283-291.

Tomassetti P, P Gennaro, L Lattanzi, I Mercatali, E Persia, D Vani \& S Porrello. 2016. Benthic community response to sediment organic enrichment by Mediterranean fish farms: Case studies. Aquaculture 450: 262-272. 
Turner RE, NN Rabalais \& D Justic. 2006. Predicting summer hypoxia in the northern Gulf of Mexico: Riverine N, P, and Si loading. Marine Pollution Bulletin 52: 139-148.

Vila M, E Garces, M Maso \& J Camp. 2001. Is the distribution of the toxic dinoflagellate Alexandrium catenella expanding along the NW Mediterranean coast? Marine Ecology Progress Series 222: 73-83.
Yokoyama H. 2003. Environmental quality criteria for fish farms in Japan. Aquaculture 226: 45-56.

Yucel-Gier G, F Kucuksezgin \& F Kocak. 2007. Effects of fish farming on nutrients and benthic community structure in the Eastern Aegean (Turkey). Aquaculture Research 38: 256-267.

Received 12 April 2017 and accepted 30 July 2018

Editor: Claudia Bustos D. 